\title{
6 \\ Sewers, Sociality and Mangrove Swamps
}

Faecal pollution is seldom noticed. As Dr R. A. Edwards, researcher at the University of New South Wales, commented in 1969, if river water is apparently clear 'it is hard to believe it could be highly polluted'. ${ }^{1}$

For the Picnic Point campaigners, it was factory pollution about which they were most worried. Many of those interviewed spoke about toxic liquids dumped or spilled into the river by the increasing number of factories sited along its banks. Factories had been sited on upper Salt Pan Creek and around Bankstown from the 1920s. ${ }^{2}$ The soldier settlement area at Milperra, having had an unstable resident body ever since its failure to support the servicemen after World War I, was being opened up as an industrial area in 1967. Confirming her brother Col's memories, Carol Jacobsen recalled him telling her about a time when George had 'come home all upset because there was a new factory going up on the river and it was going to be spewing shit into the river'. ${ }^{3}$

1 Commonwealth of Australia, Senate Select Committee on Water Pollution, Minutes of Evidence, vol. 8,4683 .

2 See H. C. Hunt on lead contamination in upper Salt Pan Creek, plus other factory chemical discharges, (the content of none of which were able to be recorded) in Commonwealth of Australia, Senate Select Committee on Water Pollution, Minutes of Evidence, vol. 20, 4633. Residual heavy metal contamination in riverbed sediments is confirmed in Birch, Evenden and Teutsch, 'Dominance of Point Source'.

3 Commonwealth of Australia, Senate Select Committee on Water Pollution, Minutes of Evidence, vol. 8, 4683. Carol mentioned on a number of occasions that this story was often recounted within her family, and she repeated it during the PPRA interview, 22 March 2006. During the collective Jacobsens' interview, 12 July 2006, Colin confirmed it fully. This quote is from Carol's version of it in the PPRA interview. 
None of the interviewees remembered faecal pollution as a major problem in the river environment, despite their intense anxiety about the rising number of factories and the growing population of workers whom the factories demanded, leading to the feared loss of riverfront land to private development. As a number of expert witnesses at the 1969 Senate Select Committee were to explain, bacterial contamination from human waste was not detectable to smell or taste. It would, however, be human waste faeces and urine - that led to the greatest contamination problems on the river. Concerns were being expressed as early as 1931 about the dumping of nightsoil into the Georges River and the rising contamination of its waters. ${ }^{4}$ The effects of human waste are considered here on humans but also on what local residents regarded as the two most troublesome nonhuman species on the river: oysters and mangroves.

Despite Aird's report in 1961 and Ernest Ogg's two damning reports about bacterial contamination in the Georges River in 1962 and 1963, there had little action taken by the state's Water Sewerage and Drainage Board, responsible for the Fairfield Sewage Treatment Plant, other than heavier chlorination. ${ }^{5}$ The federal government, responsible for the Holsworthy and other sites along the river, had taken no action at all. There had been piecemeal sewerage infrastructure laid on the northern side of the river and none on the southern side by 1969. The issue of sewage pollution had not been pressed by the Georges River National Park Trust (1961-67) in which activists like George Jacobsen were intensely worried about industrial toxic pollution.

Yet the issue of faecal pollution was not unnoticed. Public pressure had successfully gained flush toilets at Bankstown Girls' High School in 1951, leading concerned residents to form 'Operation Sewerage', demanding further infrastructure extensions, although with little positive outcome. The situation grew steadily worse until, in 1967, Bankstown Council's chief health inspector, H. C. Hunt, reported to council that Bankstown faced 'a State of Emergency'. He pointed out that the rapid population rise after the war had led to gross overloading of the council's sanitary

4 'Pollution in Georges River: Danger to Health', Sun, 11 November 1931, 11; 'Twenty-Year-Long Struggle Brings Sewerage at Last to Bankstown School', Tribune, 24 October 1951, 4.

5 See Hunt, in Commonwealth of Australia, Senate Select Committee on Water Pollution, Minutes of Evidence, vol. 20, 4631. 
depot, with more than 35,000 residents and factory workers in unsewered areas relying on the 'antiquated system of nightsoil removal'. State and federal governments had both failed to fund the municipality's efforts to extend sewerage infrastructure and the nightsoil service had recently been interrupted completely for weeks because of a strike. Hunt argued that residents and factory workers were threatened by typhoid 'or some other dreaded disease' unless there was urgent change, insisting 'the problem is not one of engineering but of finance'. ${ }^{6}$

There was definitely rising political interest in the problem of water quality. Pressure from the waterfront's 'exclusive' landowners had led to Robert Askin's support in 1965 for the regulation and, by implication, removal of the oyster farming industry. His support, however, had been shown to be unreliable. Askin had refused to push for removal of the industry in the 1966 conference, despite being pressured by downstream progress associations and local government councils. Nevertheless, Askin's chief secretary, Eric Willis, was alert to the problems. Willis was the member for Earlwood, which lay between the Georges River and the Cooks River as they both neared Botany Bay. Willis was keenly aware of the environmental issues of the river as well as the land for which he was responsible. He had graduated with honours in history as well as geography and had worked as a geographer for some years before entering parliament. His department contained the Fisheries Branch, which was not only a frequent and energetic source of advice for local organisations on aquatic species and river environmental conditions but also took an active role in a number of the conflicts that emerged over the impacts of development on the Georges River.

Although the Australian Labor Party (ALP) had lost the New South Wales state election in 1965, the incoming ALP members were committed to the environmental policies that would flower in the federal Whitlam Labor government (1973) and the later state Wran Labor government (1976). The most notable of those newcomers in 1965 was Frank Walker, the member for Georges River. Walker's father had been a member of the Communist Party of Australia (CPA), and, although the party had not flourished along the river, individual members of the party had lived there, like Phyllis Johnson at Padstow and Bob Walshe at Jannali. ${ }^{7}$ There had even been a well-attended CPA 'Youth Carnival for Peace and Friendship'

6 'Bankstown in State of Emergency', Bankstown Torch, 30 August 1967, 1-2.

7 Cahill, 'An Activist for All Seasons'. 
at Hollywood Beach on the Georges River near Milperra in March 1952, although its location there had only come about because the Cold War atmosphere of the period led the party's preferred venue, the inner-city Harold Park Trotting Racecourse, to reject their booking. ${ }^{8}$

Walker had not followed his father into CPA membership, but, brought up in Papua New Guinea and in rural New South Wales, he had developed a strong awareness of racism and of landed privilege, developing a commitment in his legal education to social justice. He represented the seat of Georges River, which had been expected to return Liberal political representatives, from 1970 to 1988 . Against expectations, his personal integrity and communication skills won successive elections. Walker was aligned to the left wing of the state ALP and took an active interest in environmental matters along the river. ${ }^{9}$ He became a committed parliamentary ally for many of the campaigns we will trace in later pages.

Many Georges River residents were union or ALP members, as they often worked in industries like the railways, which had large workshops at Chullora and Everleigh. However, the Australian Railways Union, took a strongly anti-communist position, bringing a right-wing influence to the area's Labor politics. The ARU was linked to the anti-communist Industrial Groups, an alignment of conservative unions and unionists. Tony Mulvihill was one of those members of the ARU aligned with the Groupers but he also had a strong interest in environmental concerns related to water. Despite growing up at Ryde, he had worked as a railwayman and unionist, initially at the Everleigh Workshops and then at those at Chullora, as had many of the older residents along the Georges River. He became an ALP senator in the federal government from 1964 to 1983 and his concerns, as well as his constituency, drew him towards the centre of the party. He is remembered by colleagues as an advocate for migrants and a pioneer environmentalist who was a tough defender of the Colong and other national parks, and who insisted that the ALP take up the challenge of ensuring a healthier environment for all Australians..$^{10}$ One way he was to pursue his environmental commitment was in establishing a Senate Select Committee on Water Pollution, which began Australia-wide hearings in 1969 and reported in 1971. It was at this

8 Poynting, 'The Youth Carnival for Peace'; Deery, 'Community Carnival'.

9 Deborah Snow, 'Obituary', Sydney Morning Herald, 14 June 2012; 'Obituary: Francis 'Frank' John Walker', Courier Mail, 25 June 2012.

10 John Faulkner, pers. comm.; Clune, 'Mulvihill, James Anthony'; Taksa, 'James Anthony Mulvihill'. 
federal government forum, rather than at the state level conference held in 1966, that the Georges River oyster farmers were finally able to have their say, making the points discussed in the last chapter.

Much of the evidence given to this Senate inquiry about the Georges River concerned faecal pollution. After speaking out in 1967 about Bankstown's sewerage emergency, H. C. Hunt, Bankstown's chief health inspector, was eager to bring the problem to the national stage at the Senate hearings. He became its most powerful witness. ${ }^{11}$ He described the events since the Ogg reports of 1962 and 1963, which had resulted in heavier chlorination at Fairfield and other treatment plants as well as the continuation of sanitary pan collection across a wide area. Only piecemeal sections of piping for sewerage infrastructure had been constructed in the nine years since Aird's map of piped sewerage infrastructure had shown that most of the areas of the Georges River, northern and southern banks, were not serviced by flush toilets but instead by septic tanks or by weekly nightsoil pan collections. Such collected waste was delivered to sewage treatment plants like Fairfield.

Hunt explained in graphic terms what this meant:

Residents were forced to sit daily on a can of faeces and urine up to seven days old. It also meant that residents were at the mercy of a militant trade union and it was often questionable whether they received a nightsoil clearance after seven days. ${ }^{12}$

Focusing on human waste disposal at Bankstown, Hunt pointed to the role of state and federal facilities along the river: 'There are still sewage treatment works discharging into the river at Bankstown Airport, East Hills Migrant Camp, Holsworthy Military Camp, Liverpool and Campbelltown. ${ }^{13}$ It was clear that Hunt was most familiar with those areas on the upper estuary, in the Bankstown Council area, from Liverpool to Salt Pan Creek. He gave no consideration to the substantial discharge from overflowing or poorly constructed septic tanks along both sides of the lower estuary, from Salt Pan Creek to Botany Bay. Nor did he consider the weekly sanitary pan collection along the northern shores of

11 'Bankstown in State of Emergency', Bankstown Torch, 30 August 1967, 1-2.

12 Hunt's evidence was taken on 5 August 1969. See Commonwealth of Australia, Senate Select Committee on Water Pollution, Minutes of Evidence, vol. 20, 4627-67. The committee reported in June 1970. See Commonwealth of Australia, Senate Select Committee on Water Pollution, Report, 4629.

13 Commonwealth of Australia, Senate Select Committee on Water Pollution, Minutes of Evidence, vol. 20, 4630 (see Hunt, 'Municipality of Bankstown: A Case Study', 4628-34). 
the lower estuary, in the Hurstville Council area. This was dumped at what is now Gannons Park, at the top of Boggywell Creek, the western arm of Lime Kiln Bay. Nor did he mention the agricultural waste from the lower intensity land uses in the same area, like the pig farm that released effluent directly into the river.

What Hunt did point out, however, was that waste disposal was only part of the problem, because there had been no provision at all for sullage the wastewater after all other household activities - virtually all of which flowed directly into the river. This was not just a problem for those in the inner-Bankstown area. Across the whole local government area, Hunt explained, there was a group of people:

Equal to the combined populations of Bathurst and Orange without sewerage, and in the absence of this basic form of sanitation, the creeks and watercourses inevitably become polluted and in turn contribute to the pollution of the river. ${ }^{14}$

Even this was not the end of Hunt's evidence. Beyond the sewage pollution of the Georges River, by 1969, there was a significant burden of toxic industrial waste as well flowing into the river. As discussed earlier, a very high proportion of the city's expanding number of factories had been located in the Georges River area. ${ }^{15}$ This increased the risk of contaminants being released into the water, as there was no regulation over the content of waste released into the river, only over the amount released. By 1970 there was additional concern as new industrial areas were opened up on the old abandoned soldier settlement farm blocks at Milperra. ${ }^{16}$ As an exasperated Health Inspector Hunt pointed out in his submission to the Senate Select Committee, there was simply no means of knowing what chemicals were being dumped into the river - industries were not required to report the composition of their waste and there was no adequate testing methods for all the many thousands of chemicals that might be going into the water.

14 Ibid., 4630. Bathurst and Orange were both large country towns.

15 Aird, The Water Supply; Logan, 'Suburban Manufacturing'; Butlin, Sydney's Environmental Amenity; Coward, Out of Sight, Spearritt, Sydney's Century.

16 Commonwealth of Australia, Senate Select Committee on Water Pollution, Report. See Hunt's evidence in August 1969 and his written submission reported in Bankstown Torch, 4 March 1970. The New South Wales Clean Waters Act 1970 was passed in mid-1970. The New South Wales State Pollution Control Commission was one outcome of this Select Committee, empowered by an Act passed in December 1970, although it had no regulatory power until 1974. 
As Hunt gave evidence to the federal Senate inquiry, a new Bill was before the state parliament - the New South Wales Water Pollution Control Bill - which promised to mandate standard maximum discharges into the river for each chemical. This Bill had arisen because it was not only Hunt who had been concerned about the worsening damage to the Georges River among others. Many voters had become increasingly anxious, particularly in urban areas, about increasing air and water pollution. So the Bill was passed in December 1970, resulting in a new body, the State Pollution Control Commission (SPCC), although this was not given any real power until mid-1974. Yet, from its inception, the SPCC offered another body to which local government could appeal for support for waste disposal through reclamation plans. This was a strategy to which Kogarah Council was to resort in relation to Oatley Bay, discussed in Chapter 12. Hunt argued that this state legislation would be simply unworkable: not only would it take months for contaminant testing to be finalised, but also each factory might produce waste containing hundreds of chemicals. So any testing would be bogged down in the impossible task of measuring the amount dumped of each of thousands of chemicals in the water, let alone in trying to work out where they came from. Hunt had already reported this to council ${ }^{17}$ and he also explained the problem to the Senate: the only option, in his view, was total prohibition - no toxic material at all should be released into the river.

Hunt proposed that all discharges were to be made into the sewer, which would entail a cost to the industry, with specified, particularly toxic chemicals, to be removed and treated by qualified disposal, again at the cost of the industry. He recognised that industries would try to circumvent the cost by continuing to dump illegally and so he insisted that rigorous policing and strong regulation was required to ensure that no hazardous material was dumped into the river. It was the same problem across Australia, arising from the same emerging economic and social conditions and he insisted that the federal government should take responsibility for the development and cost of a uniform waste management approach across all states and territories.

Hunt gave a chilling warning to the federal government in his submission to the Select Committee, identifying the environment of the river and its water quality as 'heritage': 'While governments are actively encouraging the

17 Hunt, Garbage Disposal; Commonwealth of Australia, Senate Select Committee on Water Pollution, Transcript of Evidence, vol. 8, 4632. 
development of industry to improve Australia's prosperity, it is necessary to ensure that our heritage is not destroyed in the process. ${ }^{38}$ Despite his concerns about toxic industrial discharge, Hunt was emphatic: sewerage was the most urgent necessity in the struggle to address water quality. He was equally emphatic about the responsibility: the federal government must bear the burden.

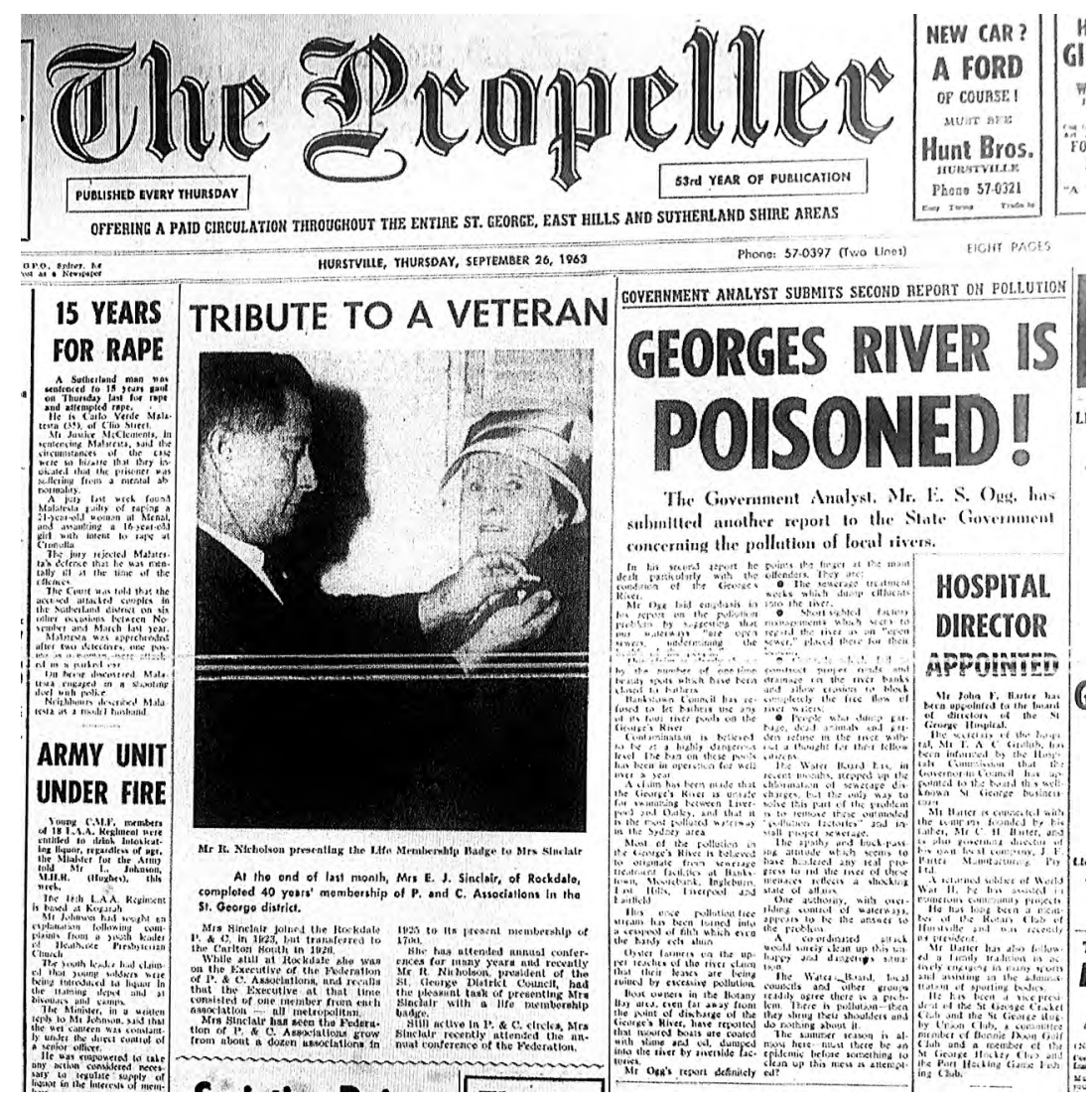

Figure 6.1: 'Georges River is POISONED', Propeller, 26 September 1963, front page.

The Propeller summarised Ogg's report, stating: 'this once pollution-free stream has been turned into a cesspool of filth which even the hardy eels shun'. The Georges River and other waterways, it said, had been turned into 'open sewers, undermining the health of the people'. Courtesy of State Library of New South Wales.

18 Commonwealth of Australia, Senate Select Committee on Water Pollution, Minutes of Evidence, vol. 8,4632 . 
Hunt's pleas persuaded the members of the Senate Select Committee to make the Georges River into an example of Australia's urban water pollution crisis. His submission on the Georges River was drawn on repeatedly for the graphic language with which the overall report addressed water contamination in cities around Australia as well as in rural areas. The committee's final report stated that New South Wales faced the greatest water pollution problems and made the Georges River its highest profile case study illustrating urban water pollution from sewage and industrial toxicity. ${ }^{19}$ The cover photo of the committee's report showed Salt Pan Creek, describing it as 'one of the most grossly polluted streams in the State'. ${ }^{20}$

Pollution, from whatever source, was one issue on which George Jacobsen and some of the council and trust officers could find strong agreement. Hunt became a member of the trust, with Kevin Howard, senior health inspector, appointed in 1975. ${ }^{21}$ Both had been involved in the testing by Ernest Ogg that led to the closure of the river due to faecal contamination in 1962. The overall question of pollution, from whatever source, was a shared concern that allowed new alliances to be built. The pressures were intense, as George Jacobsen's sons, Kevin and Col, remembered. They recalled how furious George had become when, as a trust member, he was offered a bribe to vote in favour of a developer's plan to subdivide one of the areas zoned for parkland:

Kevin: I remember him going to fight some developers that wanted to develop all along the river.

Col: They offered him money to change sides. Developers! To throw his vote to open up this particular lot of land. And he never had any money! He was in business! Five times I think he went broke before he quit. He never had much black letters against his name in the bank and they offered him big sums of money.

Kevin: That's what I'm talking about. It was offensive to him.

Colin: And he did want to fight them too. The fact that they'd even offered him that! He was horrified. ${ }^{22}$

19 'Bankstown Evidence Used in Water Pollution Report', Bankstown Torch, 15 July 1970, 1.

20 Ibid.

21 Howard joined the trust as a trustee on 20 June 1975. See Application for Reappointment to Trust, 1985, Trust Appointments - Georges River SRA 1992/SR/109/32, National Parks and Wildlife Service - Georges River National Park Trust (NPWS Archive), Hurstville Library, Georges River Council Libraries.

22 Kevin and Colin Jacobsen, interview, 12 July 2006. 
This may have been the reason that, despite increasing pressure from the state government to force community and local government members out of the trust, George Jacobsen persisted. He stayed on until he was 70 , the last community representative left on the trust.

\section{Sociality and its Limitations}

The Picnic Point Regatta Association (PPRA) saw little role for itself after the first few years of the national park's existence. It considered dissolving itself in 1965 but rescinded the decision and instead withdrew from public activity, taking part only in occasional local fundraising. ${ }^{23}$ Then, in 1967 , the national park was downgraded to a 'state recreation reserve'. The state government had created its own National Parks and Wildlife Service (NPWS) to implement its decisions and had decided on criteria for the category of 'national park'. Its definition was related to scale and to the quality of 'wilderness', and on neither of these did the Georges River park qualify as being of 'national' significance. The trust continued but the state government exercised ever more power through its NPWS member. Local people appealed to their political representatives like Joe Kelly and Pat Rogan to protest to the state government about the reduction in their input, but the NPWS and state government view was that 'the Trust must accept the concept of a State Recreation Area as being a regional rather than a local park. ${ }^{24}$

Although the first national park was short-lived and the PPRA had withdrawn from public activity even before the park was demoted, this period left a strong impression. The experience of participating in the trust had soured local activists and disabused them of any misapprehensions that their interests were going to be prioritised by local government let alone by state or federal governments. While alliances may have been built with officers like Howard and Hunt working for the councils (although Hunt's documents and Howard's interview showed little awareness of the activist groups), it was also the case that the councils were more intent on responding to the interests of local business or local organisational pressure

23 Correspondence with the Chief Secretary's Department, 16 October 1965, Bankstown Council, 29 August 1967, Picnic Point Regatta Association Archive, Alf Stills Collection. Davies notes that the PPRA was formally dissolved in the following year, 1968, in Davies, Mulholland and Pipe, West of the River Road, 39-40.

24 A. J. Chaplin, state recreation area liaison officer, to administrator state recreation areas, 13 April 1982, Trust Appointments - Georges River SRA 1992/SR/109/32, NPWS Archive. 
in their planning goals as far as these offered solutions to the pressing problems of waste management that the councils faced. Disillusionment with both state and local government was only compounded during the campaigns defending local Georges River environments that began to emerge from 1967.

Yet the very quality that had contributed to the strength of the PPRA and its campaign - the tight-knit solidarities within the communities of East Hills and Picnic Point that have been so evocatively described by PPRA members and the Jacobsen family - were also the campaign's limitation. As pointed out earlier, there were parallel socialities occurring along the river at the same time as the shared community events of the Anglo-Irish families in the PPRA. There appears to have been no interaction between the PPRA campaign for a national park and the many Aboriginal families who continued to live along Prospect Creek and Salt Pan Creek, as well, no doubt, as in other areas. This was despite the frequent assertions in the Jacobsen family that Aboriginal people had understood the land better than the invading British had done. Nor was there any interaction with the Italian and German communities who were holding comparable but less public social events in the immediate area. It is ironic that a staunch environmental advocate like Senator Tony Mulvihill, in the governing party from 1973 to 1975 , who was, at the same time, such a close ally of Australia's immigrant communities, was not able to achieve some communication between these two core values of a future nation. Sharing social interactions and building social solidarities were the common activities within all these groups and yet there was no interaction or collaboration - or even communication - between them, although there was eventually to be some common meeting ground in political parties.

The new NPWS did not address this problem at all. While wanting more women and more 'citizen members' who were sympathetic to the NPWS aims, the state government did not at any time reach out to the nonAnglo communities now entering the area. In a graphic example, in 1982, the state government expressed dissatisfaction with the community representatives on the board, asking the trust to increase its number of 'citizen representatives' to ensure more women and more environmentally active members, but it did not express any concerns around the lack of ethnic diversity on the trust. ${ }^{25}$ In the same year, in the only (surviving)

25 Gleeson, private secretary on behalf of minister for planning and environment, Eric Bedford, to the director, National Parks and Wildlife Service, D. A. Johnstone, 31 May 1982, Trust Appointments - Georges River SRA 1992/SR/109/32, NPWS Archive. 
trust document even to acknowledge the area's demographic change and cultural diversity, it proposed that parks offered an opportunity to erase diversity through 'assimilation':

Ethnic family groups make up a fair proportion of our visitors. It is obvious that our park areas provide facilities for both passive and active recreation for these people, thus enabling speedy assimilation to the outdoor Australian way of life, especially the children. ${ }^{26}$

Then, in 1987, the director of NPWS acted to remove all local people from trusts except where necessary for local communication. ${ }^{27}$

The membership of the trust, particularly after the park's downgrading to a state recreation reserve in 1967, was predominantly male Anglo professionals (often involved in local government related jobs or ex-councillors) of middle age and older. Most were long-term residents of the area - especially from the Panania, Revesby and Bankstown areas but were nevertheless members of elite groups or were council members. ${ }^{28}$

\section{Resurgent Nature}

During the period in which the Georges River National Park came into existence and was then undermined, and at the same time as community concern was rising over contamination of the river's water, mangroves were expanding. Their expansion is unarguably demonstrated in the aerial military photographs taken annually from $1930 .{ }^{29}$ Many residents were becoming uncomfortably aware of this expansion and were uneasy about its impacts. ${ }^{30}$ The conflicts over mangroves that took place among the Georges River National Park campaigners have been described above.

26 Mr LeClerc, Address of Welcome, GR SRA Trust, 9th Annual Conference of Trustees of SRAs, 28-29 October, Bankstown, 1982 Trustees Conference - Georges River SRA, 1992/SR/201/290, NPWS Archive.

27 Minute from Meeting 18 October, 1987, Trust Appointments - Georges River SRA 1992/ SR/109/32, NPWS Archive.

28 From perusal of membership lists, held in SRA 1992/SR/109/32, NPWS Archive, undertaken by Allison Cadzow, 2006.

29 Haworth, 'Bush Tracks and Bush Blocks'; Haworth, 'Changes in Mangrove/Salt Marsh Distribution'; Saintilan, 'Relationships between Height and Girth of Mangroves'; Saintilan and Williams, 'Mangrove Transgression into Saltmarsh'; Saintilan and Williams, 'The Decline of Saltmarsh in Southeast Australia'; McLoughlin, 'Estuarine Wetlands Distribution'.

30 Williams, The River in Sydney's Backyard; Molloy, A History of Padstow; Molloy, The History of Milperra; Molloy, The History of Panania. 
Some of the national park advocates, like Alf Stills, wanted the mangroves removed to create picnic grounds while others, like George Jacobsen, saw the mangroves as an integral part of the river shore value as a national park. In fact, these conflicts betrayed rising differences about how to deal with mangroves in general as well as with their expansion. The activists did not ask - at least not publicly - why this change in mangrove behaviour was occurring. The scale of the human population's expansion in Sydney and, particularly, in the Georges River area, and concomitant increase in sewage flowing into the river, offers a possible explanation. Aird, Ogg and Hunt had all warned about the continuing drainage of human waste into the river.

Faecal contamination, along with the industrial pollution that, as Hunt pointed out, was impossible to specify as there were not accurate reports of its content or volume, had increased the nutrient level, particularly of nitrogen and phosphorus, for vegetation along the river shoreline. How do mangroves and saltmarsh respond to increased nutrient levels?

Some assumed that it was inevitable that mangroves would thrive in highly populated areas, implying that the increased nutrients from human waste were beneficial. ${ }^{31}$ However, the results of scientific studies were mixed. Some studies indicated that, in both tropical and temperate areas, mangroves accelerated their growth, particularly their underground root stock, in response to increased nutrient supply, thus obstructing some flow of tidal water to saltmarsh. ${ }^{32}$ Other work pointed out that mangroves in the Australian environment, and particularly those in temperate areas, had adapted over long time periods to low nutrient environments, and so were perhaps disadvantaged by increased nutrient levels. The most comprehensive study argued that, while in general mangroves in Australia had survived on low nutrient environments, their adaptations have offered them an increased plasticity in their responses - that is, while they could survive well in low nutrient environments, mangroves were still also able to respond to, and benefit from, increases in nutrient level. ${ }^{33}$ So local conditions could still shape the overall outcomes in the expansion of mangroves. In this case, mangroves in the Georges River area are likely to have increased their growth rates as a result of increased nutrients in the water, although it is still unclear whether this offered mangroves

31 Tyrrell, River Dreams, 230.

32 Alongi, 'Impact of Global Change'.

33 Reef, Feller and Lovelock, 'Nutrition of Mangroves'. 
a competitive advantage over saltmarsh. Just as important, however, is how such increased nutrients may have affected underwater vegetation such as Zostera.

While diversity in growth rates may have been shaped by local variations in nutrient levels as well as, for example, changing salinity due to higher rates of freshwater draining from paved surfaces, there have been wider changes over this period that are significant in mangrove expansion. Neil Saintilan and Kerrylee Rogers have argued that rising temperatures have influenced the expansion of both coastal temperate mangroves in estuaries and inland 'woody weed' (immature, coppicing eucalypts), which emerged in the same period across grasslands like that in western New South Wales. ${ }^{34}$ This is an extremely important observation. Because mangroves appeared to be increasing close to dense urban populations that were releasing high levels of waste (and nutrients) into the water ways, it was easy to assume that the increased nutrient levels associated with dense urban populations had caused the mangrove increase. Yet the 'woody weeds' were becoming more abundant in marginal and arid areas, like the wide plains around Cobar, far away from any dense human or animal populations. So, it could not be simply 'urban conditions' or higher nutrient levels thar were causing the expansion.

More recently, Saintilan's work with Rogers and others has suggested that rising sea levels, associated with climate change-induced temperature rises, have led to a global expansion of mangroves into areas previously dominated by saltmarsh, which has been disadvantaged by longer immersion. They reviewed studies over long periods of time - investigating the archaeology of swamps in the Holocene - as well as a global range of sites that have demonstrated mangrove encroachment onto saltmarsh. Such sites are in the US, Central America, South America, Australia, South Africa and China. Their 2019 article concludes:

The changing distribution of mangrove and saltmarsh may serve as an important indicator of climate change impacts, a sentinel of change for the broad range of ecosystem services dependent on these habitats ... Environmental variability can therefore profoundly influence the competitive interactions between mangrove and saltmarsh ... In South East Australia and New

34 Saintilan and Rogers, 'Woody Plant Encroachment of Grasslands'. Woody weed grows in remote areas, far removed from large urban populations, undermining any easy assumptions that expansions were somehow due to proximity to dense human settlements. 
Zealand, the growth of the mangrove A. marina will be aided not only by increased temperatures toward its southern limit of distribution but also by higher sea levels. ${ }^{35}$

Overall, Saintilan and others point to the expansion of mangroves and their encroachment onto saltmarsh as early signs of climate change. ${ }^{36}$ This was not something that activists or councils were aware of in the 1960s. All they saw were mangroves expanding. It became very clear, as the following accounts show, that council arguments were framed within many of the older mythologies about mangroves but were also shaped by recent wartime experiences in tropical war zones. On the activist side, the rising influence of ecology (and selective use of metaphors drawn from biological sciences) was mobilised in conflicts over what should, or could, be done about mangroves. Mangroves were increasingly seen as offering safe spaces and nutrients for immature fish and crustaceans - as essential elements for river health through filtering and slowing its flow as they nurtured the life of the river.

The oyster farming industry was the only one on the Georges River that may have gained any benefit from increased numbers of mangroves, as it began its resurgence in the 1950s. It had, after all, used mangrove wood in its early development to catch oyster spat as oysters spawned upstream. But the industry had exhausted the supply of Georges River mangroves in the early twentieth century. Older oyster farmers interviewed for this study, beginning their farming career in the 1940s, had early memories of travelling to the Minnamurra River, 150 kilometres south, to gather red mangroves for the oyster spat. Just a few years later, in the 1950s, oyster farmers were no longer catching spawn at all in the Georges River. Instead, they bought young oysters from Port Stephens to the north and brought them back to mature and 'fatten' on hardwood racks in the rich waters of the Georges River.

35 Saintilan, Rogers and McKee, 'The Shifting Saltmarsh-Mangrove Ecotone'.

36 There may, however, be a limit to any relative advantage that climate change has offered to mangroves. Recent modelling, led again by Neil Saintilan, shows that, for worst-case outcomes with intensifying climate change on tropical coastlines, sea levels would rise so rapidly that mangroves would not be able to grow quickly enough to survive. Saintilan et al., 'Thresholds of Mangrove Survival'; Saintilan, Rogers, Kelleway, Ens and Sloane, 'Climate Change Impacts'; Woodroffe, Rogers, McKee, Lovelock, Mendelssohn and Saintilan, 'Mangrove Sedimentation'. 
This text is taken from Georges River Blues: Swamps, Mangroves and Resident Action, 1945-1980, by Heather Goodall, published 2022, The Australian National University, Canberra, Australia.

doi.org/10.22459/GRB.2021.06 